\title{
Assessment of the Climatic Condition's Impact on Volatiles, Polyphenols and Mineral Contents in Tunisian Olive Tree (Olea europaea L.)
}

\author{
Samia Ben Mansour-Gueddes ${ }^{1 *}$, Dhouha Saidana-Naija ${ }^{1}$, Guido Flamini², \\ Imed Cheraief $^{3}$, Mohamed Braham ${ }^{1}$ \\ ${ }^{1}$ Olive Tree Institute, Ibn Khaldoun BP 14, 4061, Sousse, Tunisia \\ ${ }^{2}$ Università di Pisa, Dipartimento di Farmacia Via Bonanno 33, 56126 Pisa, Italy \\ ${ }^{3}$ Faculty of Medicine, Monastir 5019, Tunisia
}

Received: 25 September 2020

Accepted: 11 February 2021

\begin{abstract}
The severity of climate causes biochemical and nutritional changes in plants. Our study focuses on the adaptation of the olive tree to the climatic conditions by the improvement of essential oils, polyphenols and macro-elements synthesis in leaves, stems and roots of Meski, growing under various bioclimatic zones of Tunisia (North, Centre and South). The mineral content was determined using a flame photometer and the volatile components were analyzed by GC-FID and GC-MS. Meski cultivar resists to severe climatic conditions, in maintaining its nitrogen content almost constant in leaf and wood for all studied areas. Moreover, leaves showed richness in calcium and sodium than roots for all areas. The GC-MS analysis of Meski leaves allowed the identification of fifty seven components. The main constituents were (E)- $\beta$-damascenone, nepetalactone, geranic acid, (E)- $\beta$-damascone, (E)-nerolidol, (E)-2-decenal whose levels varied significantly with climate conditions. In fact, to adapt to the severity of climate, southern Meski leaves produced more essential oils and polyphenols than the northern ones. Therefore, the increase of essential oils and polyphenols can be considered as a response of the tree to surround aggressions and to oppose the oxidative stress that results from the severity of climatic conditions, characteristic of the southern area.
\end{abstract}

Keywords: Olea europaea, climatic conditions, essential oils, polyphenols, macro-element

\section{Introduction}

In Tunisia, olive trees cover over $33 \%$ of the agricultural area [1]. Their cultivation is of great socioeconomic importance, is spread from the North to the

*e-mail: bm_samiatn@yahoo.fr

South in varying bioclimatic conditions. Olive trees are well adapted to abiotic stress. The severity of climate causes biochemical and nutritional changes in olive trees, such as secondary metabolites and minerals.

The olive trees exchanges with the external environment, besides the energy and the water, the volatile organic compounds [2] and the nutritive elements necessary for its process. The requirements 
in these elements vary according to the environmental factors known as exogenous factors such as climate and soil and also endogenous factors such as variety, physiological stage, etc. The olive tree is endowed with a powerful root system allowing to draws nutrients from the soil which will be used to cover its needs for growth and fruiting; it mobilizes each year a certain amount of macro-nutrients $(\mathrm{N}, \mathrm{P}$ and $\mathrm{K})$ and oligo-elements $(\mathrm{Ca}$, $\mathrm{Mg}$ and S).

To adapt to climatic conditions, the olive tree must satisfy its mineral needs. The mineral status of the olive tree will reflect its state, and the level of export of nutriments. Therefore, draught stress didn't affect similarly the uptake, transport, allocation and physiological use efficiency of all minerals [3]. Indeed, the determination of the variations of nitrogen, potassium, phosphorus, calcium and sodium contents is indispensable to deduce its nutritional status and its mode of adaptation. Also, the study of the effect of water stress and climate change on the absorption of nutrients and their distribution in the various organs of the olive tree is required.

The secondary metabolites are derivatives of pentose phosphate, shikimate and phenylpropanoids pathways in plants. Their production and emission are endowed with antioxidant and thermo-tolerance properties and is therefore biochemically viable and beneficial [4]. In fact, Polyphenols, which are the biggest group of phytochemicals, have revealed significant physiologic and morphologic value in plants. These metabolites played an important role in growth, proliferation, by providing protection against pathogens and predators [5] and the plant response to climate change, being important defense compounds against oxidative stress [6]. Besides, the quantitative variation of the essential oils will reflect the role played by the volatile components in the adaptation to the climatic severity, which is summarized by the elevation of the temperature and the gradual restriction of the precipitation $[7,8]$.

To adapt to the severity of the weather, the olive tree Meski developed several strategies when water availability is limited. Therefore, the aim of this work was to evaluate the adaptation of the olive tree to the climatic conditions by the investigation of the essential oils, the polyphenols and the macro-elements synthesis in leaves, stems and roots of Meski, located in three bioclimatic areas.

\section{Experimental}

\section{Plant Material}

The leaves, the stems and the roots of the olive tree Meski were collected at flowering from three Tunisian coastal areas, Morneg (North-subhumid), (36 $40^{\prime} 51^{\prime \prime}$ North; $10^{\circ} 1725^{\prime \prime}$ Est); Chott Mariem (Centerhigher semi-arid), (35 $56^{\prime} 08^{\prime \prime} \mathrm{N}$; $\left.10^{\circ} 33^{\prime} 26^{\prime \prime} \mathrm{E}\right)$ and Zarzis
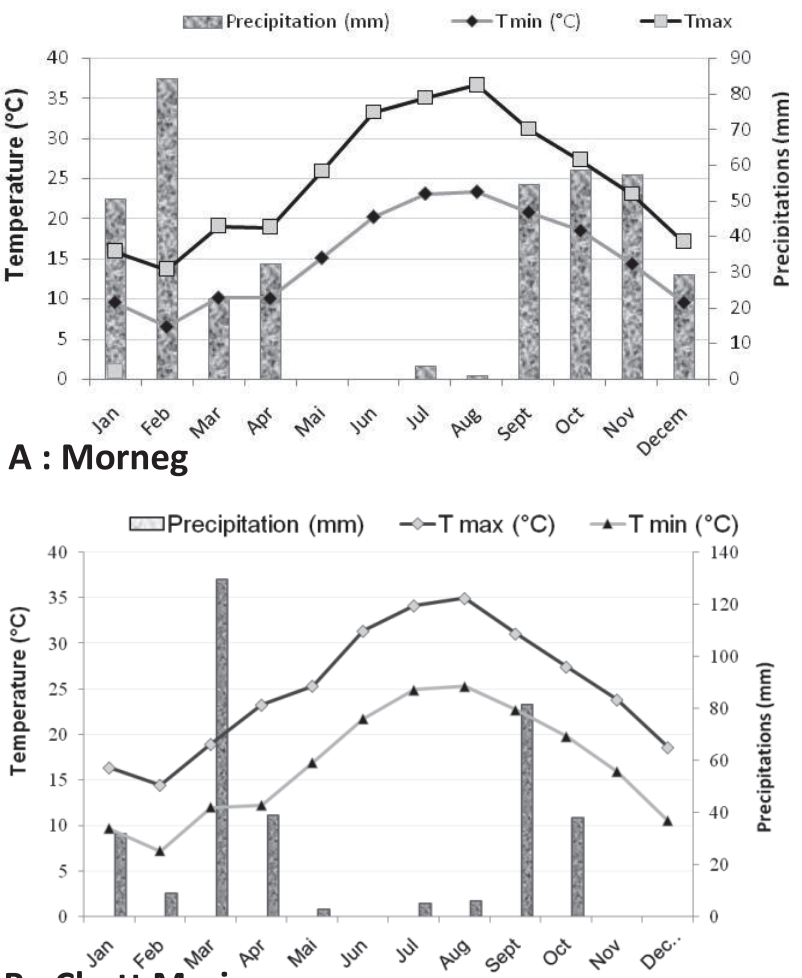

B : Chott Mariem

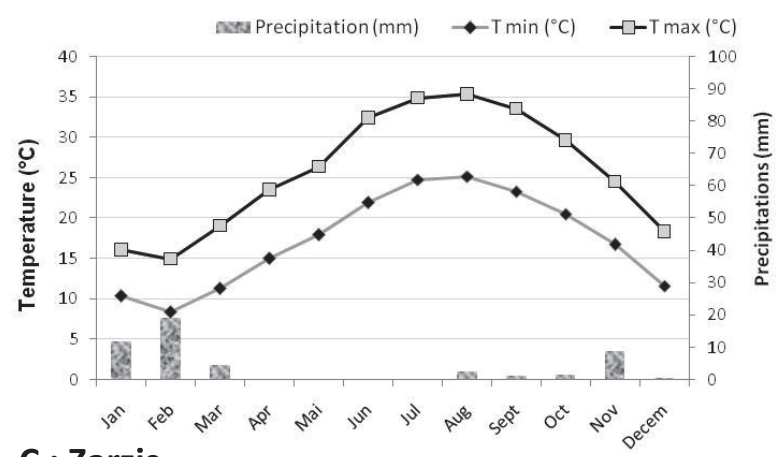

C: Zarzis

Fig. 1. Monthly average of temperature and precipitations of three Tunisian studied areas during the season 2012 (Tmax: Maximal Temperature; Tmin: Minimal Temperature and HR: Relative Humidity).

(South-lower arid), $\left(33^{\circ} 30^{\prime} \mathrm{N} ; 11^{\circ} 07^{\prime} \mathrm{E}\right)$. The study was accomplished on samples collected from different branches of twelve trees.

The average of temperature and the rainfall, illustrated in Fig. 1, were collected from the meteorological station of experimental field.

\section{Volatile Compounds Extraction}

The fresh Meski leaves were collected from the North, the Center and the South of Tunisia. Each sample was cut into small pieces, weighted and submitted to steam distillation using a rotary evaporator for six hours. The recovered solution was extracted with the hexane. After drying the extract over anhydrous $\mathrm{MgSO}_{4}$, the solvent was removed and the oil samples 
were stored in $4^{\circ} \mathrm{C}$ until further analysis. Yield based on fresh weight of the sample was calculated. Three replications were adopted.

\section{Compound Identification by Gas Chromatography-Flame Ionization Detector (GC-FID) and Gas Chromatography-Mass Spectrometry (GC-MS) Analysis}

The analysis of the volatile component was run on a Hewlett-Packard GC-MS system (GC: 5890 series II; MSD 5972) according to Saidana et al. [9]. The software adopted to handle mass spectra and chromatogram was a HP Chem-Station.

The components of the volatile fractions were identified by comparing their mass spectra with those of a computer library (Wiley 275 library). Further confirmation was done by referring to retention indices data generated from a series of aliphatic hydrocarbons (C9-C28) $[10,11]$. Percentages of the constituents were calculated by electronic integration of FID peak areas without the use of response factor correction. The percentages of volatile compounds were means of three experiments.

\section{Polyphenol Analysis}

The extracts of samples were prepared by cold maceration. In fact, $5 \mathrm{~g}$ of each dried sample was weighed, covered with a filter paper and soaked in $50 \mathrm{ml}$ of distilled water than incubated on a shaker, at ambient temperature, during three days. The samples, of different organs of Meski, were extracted with Rotary evaporator. Total phenols content in extracts were spectrometrically analyzed at $725 \mathrm{~nm}$, with FolinCiocalteu reagent, according to the method of Ryan et al. [12]. The results were expressed in mg Catechin equivalents by $\mathrm{g}$ of extract with reference to a standard curve derived from a series of catechin solutions having the following concentrations: $0.01 ; 0.02 ; 0.03 ; 0.04$ and 0.05 mg. mL-1 (Fig. 2).

\section{Mineral Analysis}

The leaves collected from various bioclimatic ranges, were dried at temperature of $70^{\circ} \mathrm{C}$ and then grounded. One gram of each sample was calcined. The determination of potassium (K), phosphorus $(\mathrm{P})$, calcium $(\mathrm{Ca})$ and sodium $(\mathrm{Na})$ contents was realized by flame photometer (Jenway, England) according to Martin-Prével et al. [13]. In addition, the nitrogen (N) level was determined in leaves, stems and roots by Kjeldahl method according to Martin-Prével et al. [13]. Three replications were applied for all samples.

\section{Statistical Analysis}

Statistical analysis was done by "SPSS 20" statistical program package. The one-way analysis of

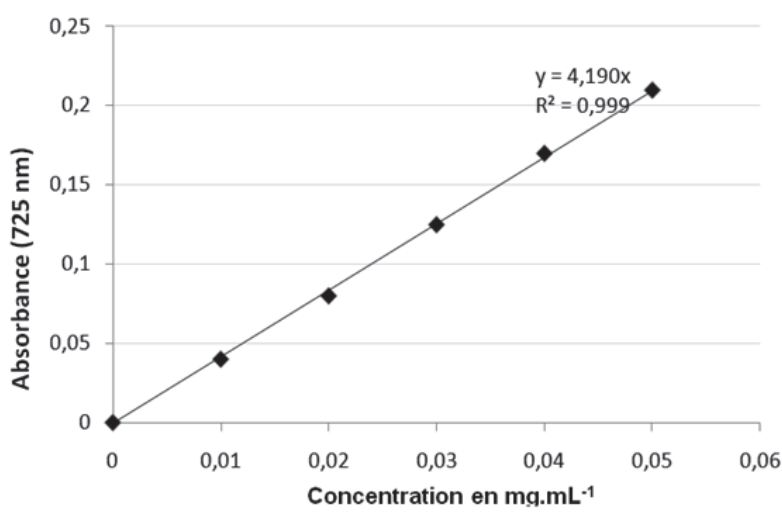

Fig. 2. Standard curve of Catechin.

variance (ANOVA) followed by Duncan multiple range test was employed and the mean value was significant at $\mathrm{p}<0.05$. Principal Component Analysis (PCA) was used to evaluate the relationships among the volatile compounds and the minerals from the progeny.

\section{Results and Discussion}

Impact of Climate Change on Volatiles

\section{Volatiles Yield}

The volatiles yield, presented in the Fig. 3, showed a significant difference between studied areas. The highest volatiles yield was stored in Southern Meski leaves $(0.016 \%)$ but the lowest was checked in Northern ones $(0.0035 \%)$. In fact, an increase of $78.78 \%$ was recorded for Meski leaves of the South compared to those of the North. These results could be explained by the dependence of the volatile compounds content on different factors, such as the olive cultivar, climatic conditions, plant mineral contents and geographic area [14]. These compounds played an important regulatory role within a plant response to environmental stress, being an important defense compounds against oxidative stress [15-18].

\section{Chemical Composition of Volatiles}

The GC-FID and GC-MS analysis of the volatile fractions of fresh Meski leaves allowed identifying fifty-seven compounds, and the constituent levels are presented in Table 1. Under bioclimatic range, the main volatiles in Meski leaves were: (E)- $\beta$-damascenone ranging from 0.6 to $13.6 \%$; 1 -hexadecene ranging from 1.1 to $16.0 \%$; (E)- $\beta$-damascone ranging from 2.5 to $6.0 \%$; n-hexadecane ranging from 1.5 to $6.5 \%$; p-cymen-8-ol ranging from 1.2 to $2.9 \%$ and $(\mathrm{E}, \mathrm{E})-\alpha-$ farnesene ranging from 1.3 to $2.4 \%$. Whereas, other constituents such as 3-methyltridecane $(12.5 \%)$; geranic acid $(11.6 \%)$; 4-methylpentadecane $(6.2 \%)$; (Z)-jasmone (5.2\%); 3-methylpentadecane (4.2\%); hexylbenzoate 
Table 1. Volatile composition of leaves of Meski growing in several bioclimatic ranges, the North, the Center and the South of Tunisia.

\begin{tabular}{|c|c|c|c|c|c|}
\hline Compounds & Chemical formulas & l.r.i. & Northern leaves & Center leaves & Southern leaves \\
\hline 3-ethyl-1,5-octadiene & $\mathrm{C}_{10} \mathrm{H}_{18}$ & 942 & $2.6 \pm 0.15$ & $0.8 \pm 0.02$ & \\
\hline Phenol & $\mathrm{C}_{6} \mathrm{H}_{6} \mathrm{O}$ & 985 & & & $1.1 \pm 0.05$ \\
\hline Octanal & $\mathrm{C}_{8} \mathrm{H}_{16} \mathrm{O}$ & 1002 & $0.2 \pm 0.01$ & & \\
\hline 2-ethyl-1-hexanol & $\mathrm{C}_{8} \mathrm{H}_{18} \mathrm{O}$ & 1031 & $1.1 \pm 0.05$ & & $0.6 \pm 0.01$ \\
\hline 1-octanol & $\mathrm{C}_{8} \mathrm{H}_{18} \mathrm{O}$ & 1072 & $1.3 \pm 0.03$ & & $1.0 \pm 0.02$ \\
\hline Linalool & $\mathrm{C}_{10} \mathrm{H}_{18} \mathrm{O}$ & 1101 & $1.0 \pm 0.01$ & & $0.7 \pm 0.03$ \\
\hline Nonanal & $\mathrm{C}_{9} \mathrm{H}_{18} \mathrm{O}$ & 1102 & $2.4 \pm 0.05$ & & $2.7 \pm 0.05$ \\
\hline phenylethyl alcohol & $\mathrm{C}_{8} \mathrm{H}_{10} \mathrm{O}$ & 1110 & $1.6 \pm 0.02$ & & $0.4 \pm 0.00$ \\
\hline 4-ketoisophorone & $\mathrm{C}_{9} \mathrm{H}_{12} \mathrm{O}_{2}$ & 1144 & $0.3 \pm 0.00$ & & \\
\hline$p$-cymen-8-ol & $\mathrm{C}_{10} \mathrm{H}_{14} \mathrm{O}$ & 1185 & $1.5 \pm 0.01$ & $1.2 \pm 0.05$ & $2.9 \pm 0.05$ \\
\hline$\alpha$-terpineol & $\mathrm{C}_{10} \mathrm{H}_{18} \mathrm{O}$ & 1191 & $1.0 \pm 0.04$ & & $1.1 \pm 0.12$ \\
\hline$n$-dodecane & $\mathrm{C}_{12} \mathrm{H}_{26}$ & 1200 & & $1.1 \pm 0.03$ & \\
\hline Decanal & $\mathrm{C}_{10} \mathrm{H}_{20} \mathrm{O}$ & 1205 & $0.7 \pm 0.01$ & & $0.6 \pm 0.01$ \\
\hline$\beta$-cyclocitral & $\mathrm{C}_{10} \mathrm{H}_{16} \mathrm{O}$ & 1222 & $1.1 \pm 0.05$ & & $0.6 \pm 0.00$ \\
\hline cis-carveol & $\mathrm{C}_{10} \mathrm{H}_{16} \mathrm{O}$ & 1231 & & $2.0 \pm 0.11$ & \\
\hline Geraniol & $\mathrm{C}_{10} \mathrm{H}_{18} \mathrm{O}$ & 1256 & $1.2 \pm 0.10$ & & \\
\hline (E)-2-decenal & $\mathrm{C}_{10} \mathrm{H}_{18} \mathrm{O}$ & 1263 & $1.0 \pm 0.03$ & & $\mathbf{2 . 4} \pm 0.21$ \\
\hline nonanoic acid & $\mathrm{C}_{9} \mathrm{H}_{18} \mathrm{O}_{2}$ & 1275 & $\mathbf{4 . 2} \pm 0.11$ & & \\
\hline 2,6,11-trimethyldodecane & $\mathrm{C}_{15} \mathrm{H}_{32}$ & 1277 & & & $1.3 \pm 0.05$ \\
\hline dihydroedulan IA & $\mathrm{C}_{13} \mathrm{H}_{22} \mathrm{O}$ & 1292 & $1.7 \pm 0.07$ & & \\
\hline$(E, Z)$-2,4-decadienal & $\mathrm{C}_{10} \mathrm{H}_{16} \mathrm{O}$ & 1294 & & & $0.3 \pm 0.00$ \\
\hline Theaspirane I & $\mathrm{C}_{13} \mathrm{H}_{22} \mathrm{O}$ & 1298 & $2.1 \pm 0.07$ & $1 \pm 0.05$ & \\
\hline 4-vinylguaiacol & $\mathrm{C}_{9} \mathrm{H}_{10} \mathrm{O}_{2}$ & 1313 & & & $0.6 \pm 0.00$ \\
\hline theaspirane II & $\mathrm{C}_{13} \mathrm{H}_{22} \mathrm{O}$ & 1315 & $2.8 \pm 0.07$ & $2 \pm 0.11$ & \\
\hline$\delta$-elemene & $\mathrm{C}_{15} \mathrm{H}_{24}$ & 1340 & & $1.1 \pm 0.03$ & \\
\hline geranic acid & $\mathrm{C}_{10} \mathrm{H}_{16} \mathrm{O}_{2}$ & 1357 & & & $11.6 \pm 0.2$ \\
\hline Eugenol & $\mathrm{C}_{10} \mathrm{H}_{12} \mathrm{O}_{2}$ & 1358 & $1.1 \pm 0.06$ & & $\mathbf{3 . 3} \pm 0.11$ \\
\hline methyl 4-formylbenzoate & $\mathrm{C}_{9} \mathrm{H}_{8} \mathrm{O}_{3}$ & 1370 & $2.6 \pm 0.12$ & $10.6 \pm 0.17$ & \\
\hline Nepetalactone & $\mathrm{C}_{10} \mathrm{H}_{14} \mathrm{O}_{2}$ & 1371 & $1.2 \pm 0.07$ & & $7.7 \pm 0.12$ \\
\hline 3-methyltridecane & $\mathrm{C}_{14} \mathrm{H}_{30}$ & 1373 & & & $12.5 \pm 0.08$ \\
\hline (E)- $\beta$-damascenone & $\mathrm{C}_{13} \mathrm{H}_{18} \mathrm{O}$ & 1382 & $9.7 \pm 0.13$ & $13.6 \pm 0.25$ & $7.7 \pm 0.1$ \\
\hline 10-acethylmethyl-3-carene & $\mathrm{C}_{13} \mathrm{H}_{20} \mathrm{O}$ & 1389 & $6.4 \pm 0.05$ & & \\
\hline 1-tetradecene & $\mathrm{C}_{14} \mathrm{H}_{28}$ & 1392 & $0.4 \pm 0.07$ & $\mathbf{8 . 5} \pm 0.03$ & \\
\hline (Z)-jasmone & $\mathrm{C}_{11} \mathrm{H}_{16} \mathrm{O}$ & 1395 & & & $\mathbf{5 . 2} \pm 0.15$ \\
\hline dihydro- $\gamma$-ionone & $\mathrm{C}_{13} \mathrm{H}_{22} \mathrm{O}$ & 1396 & & & $2.9 \pm 0.11$ \\
\hline$n$-tetradecane & $\mathrm{C}_{14} \mathrm{H}_{30}$ & 1400 & $1.3 \pm 0.11$ & $3.8 \pm 0.12$ & \\
\hline (E)- $\beta$-damascone & $\mathrm{C}_{13} \mathrm{H}_{20} \mathrm{O}$ & 1412 & $2.5 \pm 0.09$ & $4.7 \pm 0.07$ & $6.0 \pm 0.05$ \\
\hline dihydro- $\alpha$-ionone & $\mathrm{C}_{13} \mathrm{H}_{22} \mathrm{O}$ & 1420 & $3.4 \pm 0.12$ & & $\mathbf{2 . 5} \pm 0.10$ \\
\hline Nerylacetone & $\mathrm{C}_{13} \mathrm{H}_{22} \mathrm{O}$ & 1436 & $2.0 \pm 0.01$ & & $1.0 \pm 0.07$ \\
\hline
\end{tabular}


Table 1. Continued.

\begin{tabular}{|c|c|c|c|c|c|}
\hline trans,cis-iridolactone & $\mathrm{C}_{10} \mathrm{H}_{16} \mathrm{O}_{2}$ & 1449 & $1.6 \pm 0.2$ & & \\
\hline (E)-geranylacetone & $\mathrm{C}_{13} \mathrm{H}_{22} \mathrm{O}$ & 1456 & $2.8 \pm 0.14$ & $1.4 \pm 0.02$ & $0.7 \pm 0.00$ \\
\hline (E)- $\beta$-ionone & $\mathrm{C}_{13} \mathrm{H}_{20} \mathrm{O}$ & 1487 & $4.9 \pm 0.01$ & $2.5 \pm 0.12$ & \\
\hline 1-pentadecene & $\mathrm{C}_{15} \mathrm{H}_{30}$ & 1492 & & & $1.2 \pm 0.11$ \\
\hline$n$-pentadecane & $\mathrm{C}_{15} \mathrm{H}_{32}$ & 1500 & & $1.2 \pm 0.11$ & \\
\hline$(E, E)$ - $\alpha$-farnesene & $\mathrm{C}_{15} \mathrm{H}_{24}$ & 1507 & $\mathbf{1 . 3} \pm 0.1$ & $\mathbf{2 . 4} \pm 0.01$ & $\mathbf{2 . 4} \pm 0.05$ \\
\hline Liguloxide & $\mathrm{C}_{15} \mathrm{H}_{26} \mathrm{O}$ & 1532 & $1.1 \pm 0.01$ & $2.8 \pm 0.01$ & \\
\hline Dihydroactinidiolide & $\mathrm{C}_{11} \mathrm{H}_{16} \mathrm{O}_{2}$ & 1536 & $2.7 \pm 0.01$ & & \\
\hline 4-methylpentadecane & $\mathrm{C}_{16} \mathrm{H}_{34}$ & 1556 & & & $6.2 \pm 0.07$ \\
\hline 2-methylpentadecane & $\mathrm{C}_{16} \mathrm{H}_{34}$ & 1563 & & & $0.9 \pm 0.05$ \\
\hline (E)-nerolidol & $\mathrm{C}_{15} \mathrm{H}_{26} \mathrm{O}$ & 1564 & $11.1 \pm 0.1$ & $6.7 \pm 0.11$ & \\
\hline (Z)-3-hexenyl benzoate & $\mathrm{C}_{13} \mathrm{H}_{16} \mathrm{O}_{2}$ & 1570 & $2.3 \pm 0.10$ & & \\
\hline 3-methylpentadecane & $\mathrm{C}_{16} \mathrm{H}_{34}$ & 1574 & & & $4.2 \pm 0.12$ \\
\hline hexylbenzoate & $\mathrm{C}_{13} \mathrm{H}_{18} \mathrm{O}_{2}$ & 1580 & & & $\mathbf{2 . 5} \pm 0.11$ \\
\hline caryophyllene oxide & $\mathrm{C}_{15} \mathrm{H}_{24} \mathrm{O}$ & 1582 & & $4.4 \pm 0.10$ & $2.9 \pm 0.15$ \\
\hline 1-hexadecene & $\mathrm{C}_{16} \mathrm{H}_{32}$ & 1593 & $2.0 \pm 0.13$ & $\mathbf{1 6 . 0} \pm 0.13$ & $1.1 \pm 0.13$ \\
\hline$n$-hexadecane & $\mathrm{C}_{16} \mathrm{H}_{34}$ & 1600 & $4.6 \pm 0.3$ & $\mathbf{6 . 5} \pm 0.10$ & $1.5 \pm 0.01$ \\
\hline 3-hydroxy- $\beta$-damascone & $\mathrm{C}_{13} \mathrm{H}_{20} \mathrm{O}_{2}$ & 1616 & $1.4 \pm 0.07$ & & \\
\hline \multicolumn{2}{|c|}{ Total (\%) } & & 94.2 & 94.1 & 94.3 \\
\hline \multicolumn{2}{|c|}{ Monoterpene hydrocarbons } & & 8.0 & 0.0 & 0.0 \\
\hline \multicolumn{2}{|c|}{ Oxygenated monoterpenes } & & 5.9 & 3.2 & 24 \\
\hline \multicolumn{2}{|c|}{ Sesquiterpene hydrocarbons } & & 1.3 & 3.50 & 3.5 \\
\hline \multicolumn{2}{|c|}{ Oxygenated sesquiterpenes } & & 12.2 & 13.9 & 2.9 \\
\hline \multicolumn{2}{|c|}{ Phenylpropanoids } & & 1.1 & 0.0 & 3.3 \\
\hline \multicolumn{2}{|c|}{ Apocarotenes } & & 37.4 & 25.2 & 14.3 \\
\hline \multicolumn{2}{|c|}{ Non-terpene derivatives } & & 28.3 & 48.5 & 46.3 \\
\hline \multicolumn{2}{|c|}{ Total identified (\%) } & & 94.2 & 94.1 & 94.3 \\
\hline
\end{tabular}

The analysis of leaves extract was realized by CPG- FID and GC-MS of Meski, grown in various areas of Tunisia, Morneg from the northern areas; Chott Mariem from the center of coastal areas and Zarzis from the southern areas.

(2.5\%); dihydro- $\gamma$-ionone (2.9\%) and Phenol (1.1\%) were detected only in Southern Meski leaves.

Meski cultivar improved the volatile compounds in southern leaves such as $p$-cymen-8-ol, eugenol, (E, E)$\alpha$-farnesene, nepetalactone, (E)- $\beta$-damascone, (E)-2decenal and nonanal. The increase of these compounds with the severity of the climate could induce drought stress tolerance in Meski olive trees. This result was in accordance with those of Ben Abdeljelil et al. [16] who found relatively a similar profile in leaf volatile fraction of Chemlali cultivar sampled in April. Whereas, other volatiles such as, geranic acid, 3-methyltridecane, (Z)jasmone and 4-methylpentadecane identified only in southern leaves. This cultivar improved the level of several metabolites and synthesized some novel secondary compounds to acclimatize themselves to adverse conditions in order to survive and to protect against stress conditions [17]. These metabolites, during drought, could prevent plants and induced stress tolerance suggesting their high efficiency in scavenging reactive oxygen species (ROS) [18] to minimize the damaging effects of environmental stress, as high light, temperature, draught, on crops cultivated in arid regions $[19,20]$.

Among the oxygenated sesquiterpenes, nerolidol (Table 1) represented the major compound from northern and center Meski leaves which decreased with the severity of the climate. Also, the result demonstrated that the apocarotenes, especially (E)- $\beta$-damascenone; dihydro- $\gamma$-ionone and (E)- $\beta$-damascone, presented in 


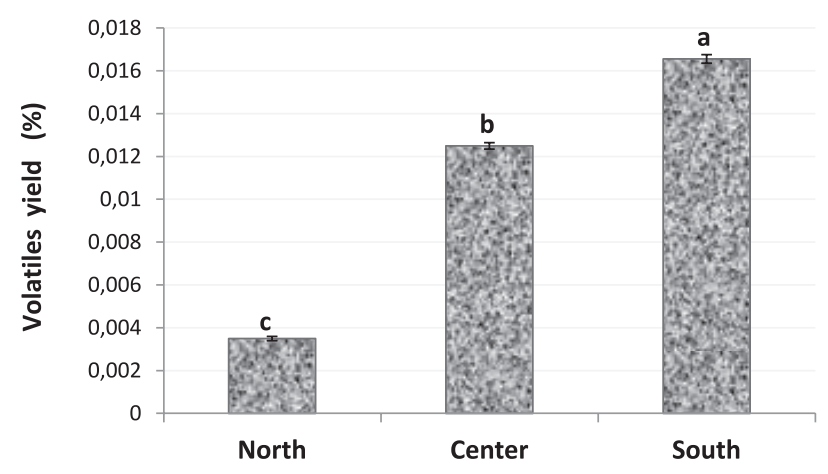

Fig. 3. Volatiles yield of Meski leaves growing in different geographic areas. Letters change: the difference is significant; same letter: the difference is not significant at $5 \%$.

leaves at significant levels in different areas. Indeed, the (E)- $\beta$-damascone has increased its amount in southern leaves. It is also important to notify that in the present study, the oxygenated monoterpenes increased in the southern Meski leaves reaching 24\%. In fact, geranic acid and nepetalactone, the most abundant, reached $11.60 \%$ and $7.7 \%$ respectively of the total volatile fractions. Furthermore, Meski leaves produced oxygenated monoterpenes compounds four times more important in southern areas than in the northern ones. The high concentration of these metabolites, in harsh climatic conditions, might result in a more resistant plant. Moreover, the increase could be attributed to environmental stress which increased the emission of green leaf volatiles in plants under stress [21].

Under harsh climatic conditions, Bertamini et al. [8] showed a strong increase in monoterpene emission upon heat stress in grapevine. Indeed, monoterpenes has been highlighted in the protection of plants against abiotic stresses [22] induced by high temperatures, high light intensity, oxidative stress by functioning as scavengers of reactive oxygen species, membrane stabilizers, or as regulators of stress responses [23, 24]. In Mediterranean conditions, the emission of isoprene and monoterpenes volatiles prevents the accumulation of toxic amounts of $\mathrm{H}_{2} \mathrm{O}_{2}$ and membrane lipid peroxidation in plants [25]. Indeed, at high temperatures, chloroplast membranes are re-modeled according to the stress perceived [26, 27].

Many recent studies believed that environmental stress and climatic factors are main stressors that influence plant physiology with stimulatory effect on secondary metabolites in crops and plants [18]. The higher production of most metabolites by the plants is part of chemical defense response system associated with increased resistance to stress. On the other hand, Yang et al. [20] showed that temperature can significantly influence the composition of secondary metabolites, and in general raising temperature might almost enhance all of secondary metabolites in plant species.

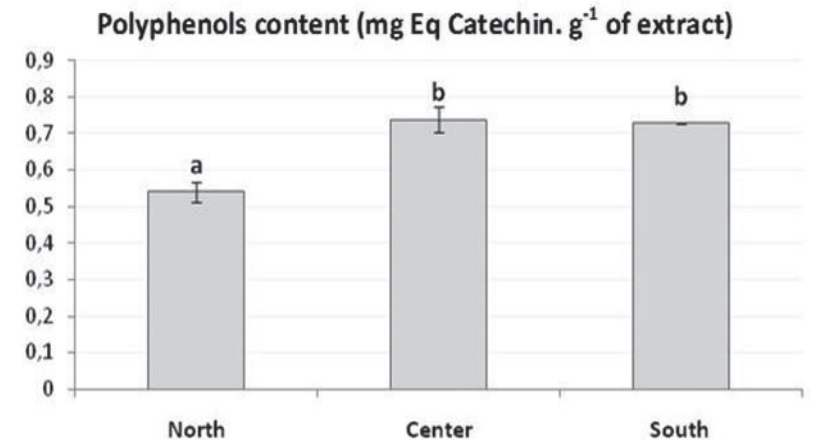

Fig. 4. Total polyphenols content in aqueous extracts of Meski leaves grown in different geographic areas. Values are expressed as means \pm standard deviation $(\mathrm{n}=3)$. Means with different letters were significantly different at the level of $\mathrm{p}<0.05$.

\section{Impact of Climatic Conditions on Total Polyphenols}

The analysis of aqueous extracts of Meski leaves collected from various bioclimatic ranges was illustrated in Fig. 4. The polyphenol content in Meski leaves varied with the geographic area and the bioclimatic conditions. Indeed, the results showed a significant increase of these compounds from the North $(0.54 \mathrm{mg}$ eq catechin. $\mathrm{g}^{-1}$ of extract) to the South $(0.72 \mathrm{mg} \mathrm{Eq}$ Catechin. $\mathrm{g}^{-1}$ of extract). Also, to be protected against oxidative stress, procured by harsh weather conditions, olive tree Meski improved phenolic compounds in center and southern leaves proving their important role in adaptation to severe climatic conditions. These results were in accordance with other studies which showed that the increase of polyphenols in harsh climatic conditions are mechanisms of trees to survival under high light and temperature [28] and drought stress conditions by scavenging ROS and maintaining cell membrane integrity [19] proving their powerful antioxidant properties.

Polyphenols content in plants are positively correlated to the temperature and growth-lighting condition which protects plants from harmful UV radiation acting as a protective filter [29, 30]. Also, these phenolics constitute as a defense system against pests, diseases and act as osmoprotectants, protecting cells from dehydration and also relieved the detoxification of stressed cells from detrimental levels of ROS to improve membrane stability [19].

\section{Impact of Climatic Conditions on Macro-Elements}

The adaptation of a cultivar to a novel environment is strongly linked to the nutrient uptake capacity [31]. Olive tree is considered a species with a great capacity to survive and produce in low fertility soils [32] and under harsh climatic conditions [33]. In fact, drought stress affects uptake, transport, and following allocation 
of minerals in the plant, causing an imbalance in plant nutrition [3].

In this study our approach was to follow the evolution of the mineral elements $(\mathrm{N}, \mathrm{P}, \mathrm{K}, \mathrm{Na}$ and $\mathrm{Ca}$ ) of the olive tree Meski according to the climatic change, as well as the distribution and the dynamics of these elements in their various organs, leaves, wood and roots.

\section{Evaluation of Nitrogen Content}

The analysis of $\mathrm{N}$ content in different organs of Meski cultivar, collected from various bioclimatic ranges, showed richness in nitrogen. Indeed, for all studied areas, leaves exhibited the highest concentrations of $\mathrm{N}$ compared to that of stems and roots. The nitrogen concentrations ranged from $1.36 \%$ in leaves to $0.54 \%$ in roots for all regions (Fig. 5). Morover, stems decreased their nitrogen levels with the severity of climate from the North to the South. Nitrogen content seemed to be more important in southern Meski roots, reaching 0.84\% than the Northern ones of $0.54 \%$. Comparing these results with those of other studies, leaf nitrogen content was lower than the threshold limits of sufficiency given by Connell and Vossen [34] (1.4 to 2\%); while, the roots exceeded the threshold limit defined by Braham [35] (0.48-0.47\%).

Under severe climatic conditions, Meski cultivar improved the uptake and the accumulation of nitrogen in their roots which would be translocated to the leaves to satisfy their needs. These results could be explained by the high demand for nitrogen during the flowering period [36, 37]. This study was in disagreement with those of Bouhafa et al. [32]. These researchers showed that during the crop cycle, Olive leaves have maintained almost the same leaf nitrogen concentration indicating a continuing olive need for nitrogen. Indeed, the critical period for $\mathrm{N}$ availability is floral induction, and more specifically, before flower bud differentiation which was explained by many researchers. Nitrogen was transported to flower and fruits, and thus lower leaf

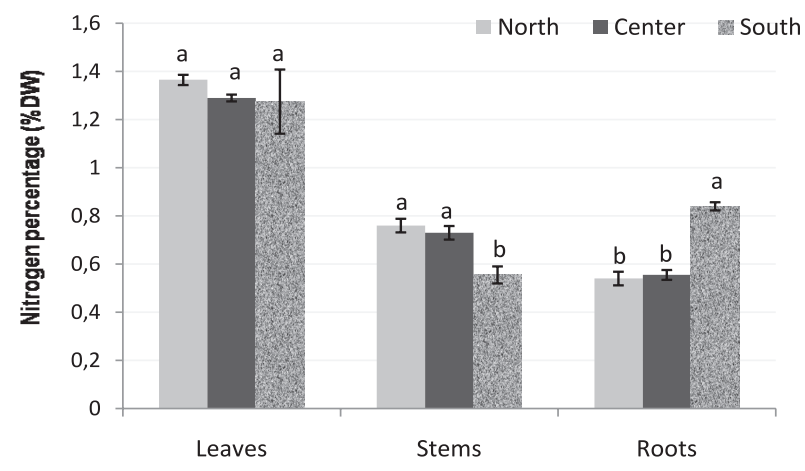

Fig. 5. Nitrogen content changes (\% of dry weight) in leaves, stems and roots of Meski cultivar grown in different geographic areas. Statistical differences are calculated by ANOVA followed by Duncan's post-hoc test $(\mathrm{P}<0.05)$. Data are means of 3 replicates \pm standard deviation.
$\mathrm{N}$ content was observed. Since, azote is essential for regulating the plant response to environmental changes and adaptation of photosynthesis to water stress [32-38].

\section{Evaluation of Phosphorus Content}

Phosphorus is an essential mineral nutrient for growth. It plays an important role in the energy storage and transfer in the cell metabolism [39, 40]. The phosphorus percentage of different organs of Meski orchard varied significantly with the bioclimatic range (Fig. 6). Indeed, in northern Meski leaves (0.085\%), the percentage of $\mathrm{P}$ was around two times more important than in the southern ones $(0.032 \%)$. For all organs, the phosphorus content has been decreased in the southern areas when the climate is arid. For Meski stems, phosphorus was dominant in the Center, reaching $0.07 \%$; reduction of $43.18 \%$ was noted in the samples of the South comparatively to the Center. For the roots, $\mathrm{P}$ content was dominant in the North and the Center, reaching $0.032 \%$; a reduction of $74.47 \%$ was noted in the sample of the South comparatively to the North (Fig. 6). We can deduce from these results, that this mineral is strongly influenced by the severity of the climate. Similarly Jin et al. [41] demonstrated that phosphorus was highly affected by the severity of the climate especially high temperature and dry climate. However, water limitations caused reduction in uptake of phosphorus and other minerals, due to lower mobility in soils under stress conditions [40].

\section{Evaluation of Potassium Content}

Potassium is a key element in the fertilization of olive orchards [42]. It is considered an enhancer of drought resistance [43]. Results (Fig. 7) showed that, for the same area, potassium content was higher in leaf than other organs and was superior than the threshold limit of sufficiency $(0.8 \%)$, defined in the literature. The potassium rate was more concentrated in leaves and stems than in roots. Indeed, leaves (1.625\%) and

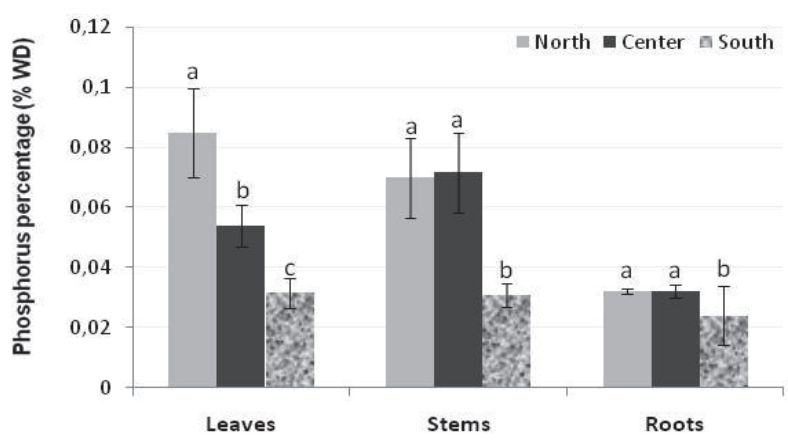

Fig. 6. Phosphorus content changes (\% of dry weight) in leaves, stems and roots of Meski cultivar grown in different geographic areas. Values are expressed as means standard deviation $(n=3)$. Means with different letters were significantly different at $\mathrm{p}<0.05$ (Duncan test). 


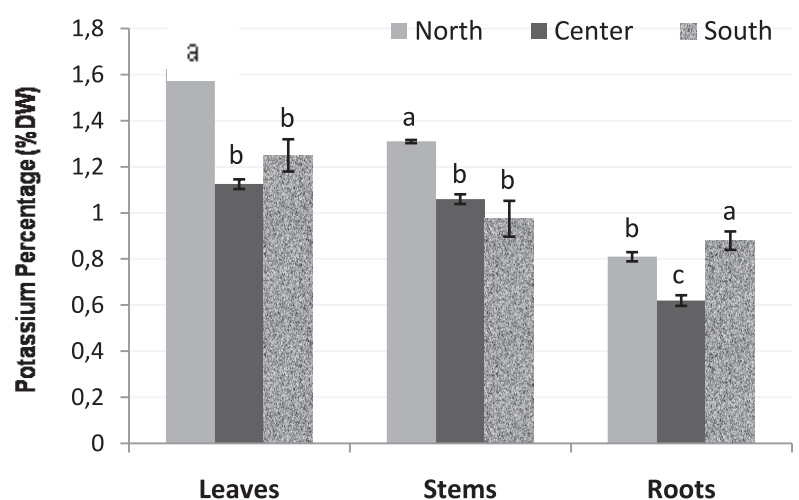

Fig. 7. Changes in Potassium content ( $\%$ of dry weight) of leaves, stems and roots of Meski cultivar grown in different geographic areas. Values are expressed as means \pm standard deviation $(n=3)$. Means with different letters were significantly different at the level of $\mathrm{p}<0.05$.

stems $(1.32 \%)$ collected from northern areas registered the highest level of this element. But the lowest concentration of $\mathrm{K}$ was noted in Center roots $(0.62 \%)$. Whereas, roots of Meski cultivar cultivated in southern areas $(0.88 \%)$ increased their potassium content. This result was in agreement with those of Cetinkaya et al. [40] which showed a decrease of $\mathrm{K}$ accumulation in leaves with the water constraint. While, Meski cultivar improved the $\mathrm{K}$ content in roots with the severity of climate to enhance drought tolerance. This increase could be attributed to the role of Potassium in the synthesis, transport and accumulation of various metabolites [44], this element accumulated significantly in olive tree to help the tolerance mechanism [45]. The $\mathrm{K}$ was indeed known to be an activator for enzymes related to photosynthesis and respiration. According to Kafkafi [46] the accumulation of potassium under stress is an insurance strategy of plant to tolerate abiotic stress. Also, many studies demonstrated water is the main factor determining the availability of mineral nutrients such as $\mathrm{K}^{+}$in the soil as well as absorption by plants and translocation from the roots to the shoot [39].

\section{Evaluation of Calcium Content}

Calcium is a mineral necessary for the regulation of many aspects of plant growth and development by playing a major role in adaptive responses as secondary messenger toward various environmental stimuli [47]. So, under environmental stress, the appreciation of calcium signaling process is crucial for improving plant productivity.

In this study, calcium analysis, in different organs of Meski cultivar, (Fig. 7) showed a significant difference between geographic areas for leaves, stems and roots. In northern area, leaves showed the highest level of calcium $(1.76 \%)$ but the lowest ones were registered in roots of the Center $(0.14 \%)$. While, Meski roots from southern areas $(2.012 \%)$ accumulated more calcium than the leaves (1.68\%) and the stems (1.19\%) (Fig. 8).

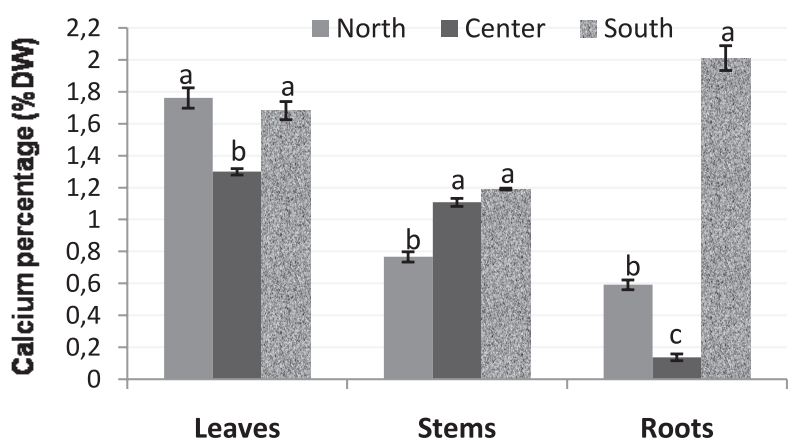

Fig. 8. Changes of Calcium content in leaves, stems and roots of Meski cultivar grown in different geographic areas. Values are expressed as means \pm standard deviation $(n=3)$. Means with different letters were significantly different at the level of $\mathrm{p}<0.05$.

This cultivar increased the level of calcium in its roots, comparatively to the other organs, especially in the southern areas. Indeed, under severe conditions, Meski cultivar increased four times calcium level in its roots to maintain the availability of a sufficient amount of $\mathrm{Ca}$ for absorption by the plant [47].

It may be assumed that maintaining higher translocation of $\mathrm{Ca}^{2+}$ is an important strategy to improve plant tolerance to drought [48, 47]. This excessive absorption of calcium will hinder the absorption of other antagonistic mineral elements, such as magnesium, phosphorus and potassium. The level of these elements in leaves was affected by environmental stress which can be the result of their lower uptake and translocation under drought condition [48].

Meski trees increase the $\mathrm{Ca}$ level to improve photosynthetic rate and drought resistance [49]. Also, the study of Hosseini et al. [48] proved that under drought stress, foliar application of $\mathrm{Ca}^{2+}$ increases the level of soluble sugars in leaves and Beetroots and increased the level of chlorophyll. The high accumulation of calcium in southern organs may be considered as an "insurance strategy" to enable the plant to better survive in sudden environmental stress [46] and to protect olive tree against $\mathrm{Na}$ toxicity [50].

\section{Evaluation of Sodium Content}

Sodium levels in different organs demonstrated dynamic geographic patterns (Fig. 9). In fact, leaves showed an increase of $\mathrm{Na}$ content from the North to the South which the highest level was recorded in the Center (0.53\%). Meski leaves accumulated more sodium than the roots for different geographic areas. However, roots increased $\mathrm{Na}$ rate in the South about 35\%. This result suggested that the severity of climate favored $\mathrm{Na}$ accumulation in roots. Meski cultivar improved $\mathrm{Na}$ level in leaves and shoots in the Center; but enhanced it especially in its roots in southern areas, to maintained tolerance to drought stress. In fact, under insufficient level of $\mathrm{K}$ and to enhance tolerance to water limitation 


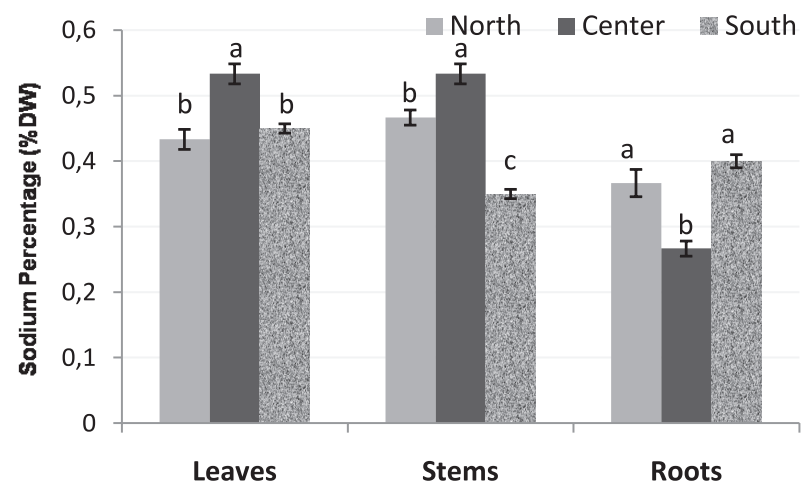

Fig. 9. Changes of Sodium content in leaves, stems and roots of Meski cultivar grown in different geographic areas. Values are expressed as means standard deviation $(n=3)$. Means with different letters were significantly different at $p<0.05$ (Duncan test).

and harsh climate conditions, olive will utilize $\mathrm{Na}$ as an osmo-regulant in vacuoles [43].

The $\mathrm{Na}$ is indispensable element who has a role in response to drought stress [48]. In fact, under insufficient $\mathrm{K}$, the high accumulation of sodium in plants can better regulate cell osmotic pressure and enhance drought resistance [51] by the improvement of stomata regulation [44].

Mineral analysis of all organs of Meski, growing in the North, the Center and the South of Tunisia, showed an important variation in macro-element content and allocation, but their highest levels are in leaves. To surround the severity of climate, Meski trees maintained the percentage of $\mathrm{N}, \mathrm{K}$ and $\mathrm{Ca}$ in their leaves and improved their levels in southern roots. Meski trees increase the level of $\mathrm{K}$ and $\mathrm{Ca}$ to enhance photosynthetic rate, plant growth, yield and drought resistance under water stress conditions [49].

\section{Principal Component Analysis (PCA)}

The correlation between volatile compounds, polyphenols and minerals analyzed by PCA was illustrated in Fig. 10. For Meski leaves, collected from different bioclimatic ranges, the multivariate data processing for macro-elements and volatile compounds allowing for a large group of diverse data samples was explained in $54.76 \%$ and $41.12 \%$ as the first and second principal components. Two factor, axe 1 and axe 2, were extracted describing approximately $98.71 \%$ of the common variance. This illustrates that there are significant differences between northern, center and southern leaves on the level of minerals, polyphenols and volatile compounds composition.

The PCA and Pearson's correlation (r) analysis showed a positive and significant correlation between polyphenols content and $\mathrm{Ca}(\mathrm{r}=0.47)$ and $\mathrm{Na}$ $(r=0.33)$ levels respectively. Also, the result showed a positive and significant correlation between the volatile compounds content, such as cymen-8-ol, eugenol, neptalactone, geranic acid, dihydro- $\gamma$-ionone, (E)- $\beta$ damascone, and the bioclimatic ranges, $\mathrm{N}, \mathrm{Ca}$, and $\mathrm{Na}$ levels. Moreover, these compounds in southern leaves were selected positively according to axis 2 , suggesting that these elements increased with the weather stress.

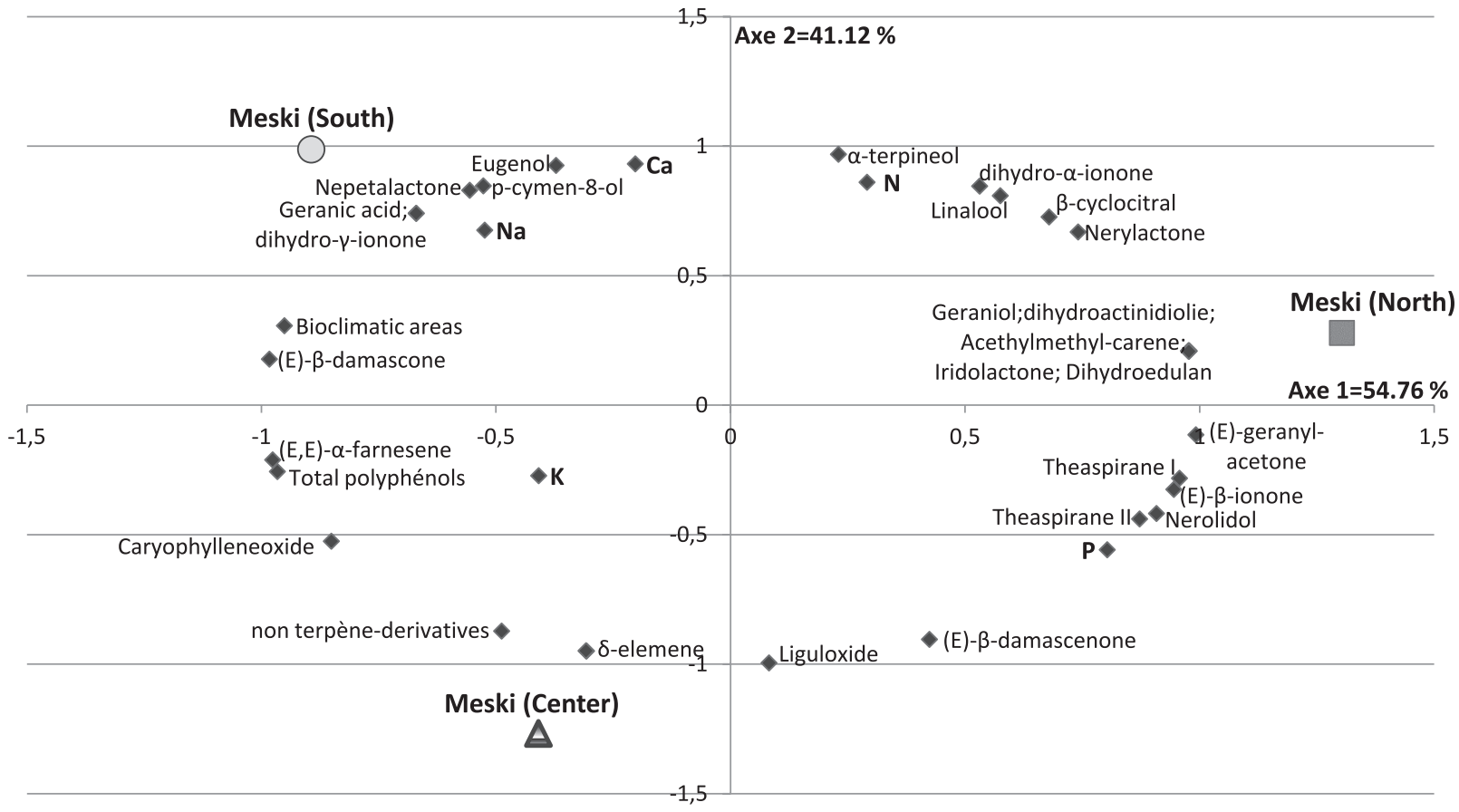

Fig. 10. Principal Component Analysis of volatiles, polyphenols, and minerals content in Meski leaves collected from the different bioclimatic range: lower sub-humid (North), higher semi-arid (Center) and, lower arid (South) of Tunisia. Factors 1 and 2 explain $95.88 \%$ of the data variation. 
While, in northern areas, $\alpha$-terpineol, linalool, geraniol were positively correlated with the axis 1 signifying that these compounds were more important in favorable climatic conditions and decreased with the severity of climate.

The changes in phytochemicals (volatiles and polyphenols) contents might be affected by changes in the mineral element uptake. Meski cultivar increased volatiles and polyphenols rate and maintained the percentage of $\mathrm{N}$ and $\mathrm{Ca}$ in their leaves and increased the level of these elements in Southern areas to enhance the photosynthetic rate and plant growth and improve the tolerance to drought stress. The improvement of volatile compounds, polyphenols in southern leaves and mineral changes seem to be efficient indicators of the adaptation of the olive tree Meski to several environmental stress conditions.

Many phytochemicals are known firstly for their powerful antioxidant capacity to cope thermal, drought and oxidative stress, secondly for their antifungal activity against pathogenic fungi for several species [18$25,52,53$ ]. In this context, Saidana et al. [53] suggested that volatiles might be an eventual source of alternative antimicrobial and antioxidant agents interesting for potential use in the biological control. These results encourage us to promote them in the agronomic sector. Their improvements protect plants from pathogenic species which could minimize the utilization of chemical pesticides that harm the environment.

\section{Conclusions}

This research showed that climate change has a notable effect on volatiles, phenolic compounds and minerals in different organs of Meski. This cultivar maintained its mineral statute in equilibrium, by way of the preservation of nitrogen and calcium rates in their leaves and increased their levels in roots. Also, to adapt to these conditions many volatiles are newly detected in the leaves and/or in the roots of Meski cultivar. Such compounds could be considered as new indicators of adaptation to stress. The polyphenols analysis of Meski leaves, collected from the North, the Center and the South, revealed significant contents. Indeed, to surround the severity of climate, the olive tree synthesized more polyphenols in southern leaves, which enjoy an important antioxidant activity. Indeed, these compounds play a major role in the adaptation of plants to their environment. Phenolic compounds were positively correlated with sodium, nitrogen and calcium contents. Management of these macronutrients can therefore be used to control volatile levels and improve plant adaptation to environmental stress. Treatment with volatiles and plant extract could be a solution to improve the adaptive capacity of the olive tree, to surround the effect of biotic and abiotic stress, and to prevent the environment against the toxicity of chemical pesticides.

\section{Acknowledgements}

This work was supported by the Laboratory of Amelioration of the Olive Tree Productivity and Product Quality. All authors are grateful to Dr. M. ABICHOU, Institute of Olive Tree, Station of Zarziz, for his contribution to collect the samples.

\section{Conflict of Interest}

The authors declare no conflict of interest.

\section{References}

1. BOULAL H., SIKAOUI L., EL GHAROUS M. Nutrient management: A new option for olive orchards in North Africa. Better Crops with Plant Food, 97 (4), 21, 2013.

2. BOUWMEESTER H., SCHUURINK R.C., BLEEKER P.M., SCHIEST F. The role of volatiles in plant communication. The Plant J, 100, 892, 2019.

3. BRITO C., DINIS L.T., MOUTINHO-PEREIRA J., CORREIA C. Drought Stress Effects and Olive Tree Acclimation under a Changing Climate. Plants, 8 (232), 2, 2019.

4. AUSTEN N., WALKER H.J., LAKE J.A., PHOENIX G.K., CAMERON D.D. The Regulation of Plant Secondary Metabolism in Response to Abiotic Stress: Interactions between Heat Shock and Elevated $\mathrm{CO}_{2}$. Front Plant Sci, 10 (1463), 1, 2019.

5. BRAVO L. Polyphenols: Chemistry, dietary sources, metabolism, and nutritional significance. In: Olives and Olive Oil in Health and Disease Prevention; Preedy V.R. Watson R. eds., Nutr Rev, 56, 317, 1998.

6. ABAZA L., TAAMALLI A., NSIR H. and ZARROUK M. Olive Tree (Olea europaea L.) Leaves: Importance and Advances in the Analysis of Phenolic Compounds. Antioxidants, 4, 682, 2015.

7. CASER M., CHITARRA W., D'ANGIOLILLO F, PERRONE I., DEMASI S., LOVISOLO C., PISTELL L., PISTELLI L., SCARIOT V. Drought stress adaptation modulates plant secondary metabolite production in Salvia dolomitica Codd. Ind. Crop Production, 129, 85, 2019.

8. BERTAMINI M., GRANDO M. S., ZOCCA P., PEDROTTI M., LORENZI S., and CAPPELLIN L. Linking monoterpenes and abiotic stress resistance in grapevines. BIO Web of Conferences 13, 01003, 2019. https://doi.org/10.1051/bioconf/20191301003.

9. SAIDANA D., MAHJOUB S., BOUSSAADA O. CHRIAA J., MAHJOUB M.A., CHERAIF I., DAAMI M., MIGHRI Z. and HELAL A.N. Antibacterial and Antifungal Activities of the Essential Oils of Two Saltcedar Species from Tunisia. J Am Oil Chem Soc, 85, 817, 2008.

10. SHIBAMOTO T. Retention indices in essential oil analysis. In: Capillary Gas Chromatography in essential oil. Chapter 8. Sandra P., Bicchi C. (eds). Huetig Verlag, Heidelberg, 259, 1987.

11. ADAMS R.P. Identification of essential oil components by gas chromatography/mass spectroscopy. Allured Publishing Corp: Carol Stream, IL, 1995.

12. RYAN D., ROBARDO K., LAVEE S. Changes in phenolic content of olive oil during maturation. Inter $\mathrm{J}$ of Food Science \& Tech, 34, 265, 1999. 
13. MARTIN P., GARRAD J., GOUTIER P. Méthodes analytiques de référence: l'analyse végétale dans le contrôle de l'alimentation des plantes tempérées et tropicales- Lavosier (editions tec et Doc). France, 1984.

14. BRAHMI F., MECHRI B., DABBOU S., DHIBI M. and HAMMAMI M. The efficacy of phenolics compounds with different polarities as antioxidants from olive leaves depending on seasonal variations. Ind Crops and Products, 38, 146, 2012.

15. ABAZA L., TAAMALLI A., ARRÁEZ-ROMÁN D., SEGURA-CARRETERO A., FERNÁNDEZGUTIERRÉREZ A., ZARROUK M., BEN YOUSSEF N. Changes in phenolic composition in olive tree parts according to development stage. Food Research Int, 3, 454, 2017.

16. BEN ABDELJELIL Z., TEKAYA M., MECHRI B., FLAMINI G., HAMMAMI M. Changes in Volatiles of Olive Tree Olea europaea According to Season and Foliar Fertilization. Int J Agric Biol, 19 (6), 1633, 2017.

17. BRITO C., DINIS L.T., MOUTINHO-PEREIRA J., CORREIA C. Role of Exogenous Salicylic Acid in Drought-Stress Adaptability in a Changing Environment, in: Improving Abiotic Stress Tolerance in Plants, Iqbal Khan M. R., Singh A. and Poor P., $1^{\text {st }}$ Edition, CRC Press, Francis and Taylor group, 119, 2020.

18. ISAH T. Stress and defense responses in plant secondary metabolites production. Biol Res, 52 (39), 2, 2019. https:// doi.org/10.1186/s40659-019-0246-3.

19. OJUEDERIE O.B., OLANREWAJU O.S., BABALOLA O.O. Plant Growth Promoting Rhizobacterial Mitigation of Drought Stress in Crop Plants: Implications for Sustainable Agriculture. Agronomy, 9 (712), 1, 2019.

20. YANG L., WEN K.S., RUAN X., ZHAO Y.X., WEI F. and WANG Q. Response of Plant Secondary Metabolites to Environmental Factors. Molecules, 23 (762), 15, 2018.

21. SCALA A., ALLMANN S., MIRABELLA R., HARING M.A., SCHUURINK R.C. Green Leaf Volatiles: A Plant's Multifunctional Weapon against Herbivores and Pathogens. Int J Mol Sci, 14, 17781, 2013.

22. HEIL M., LION U., BOLAND W. Defense-inducing volatiles: in search for the active motif. J Chem Ecology, 34, 601, 2008.

23. HAMMERBACHER A., COUTINHO T.A., GERSHENZON J. Roles of plant volatiles in defense against microbial pathogens and microbial exploitation of volatiles. Plant, Cell and Environment, 42, 2827, 2019.

24. ZUO Z., WERADUWAGE S.M., LANTZ A.T., SANCHEZ L.M., WEISE S.E., WANG J., SHARKEY T.D. Isoprene acts as a signaling molecule in gene networks important for stress responses and plant growth. Plant Phys, 180, 124, 2019.

25. LORETO F., POLLASTRI S., FINESCHI S., VELIKOV $\mathrm{V}$. Volatile isoprenoids and their importance for protection against environmental constraints in the Mediterranean area. Environ and Experimental Botany, 103, 99, 2014.

26. XU S., LI J., ZHANG X., WEI H., CUI L. Effects of heat acclimation pretreatment on changes of membrane lipid peroxidation, antioxidant metabolites, and ultra-structure of chloroplasts in two cool-season turf-grass species under heat stress. Environ Ex Bot, 56, 274, 2006.

27. LORETO F., BARTA C., BRILLI F., NOGUES I. On the induction of volatile organic compound emissions by plants as consequence of wounding or fluctuations of light and temperature. Plant Cell Environ, 29, 1820, 2006.

28. SAVIRANTA N.M.M., JULKUNEN-TIITTO R., OKSANEN E., KARJALAINEN R.O. Leaf phenolic compounds in red clover (Trifolium pratense L.) induced by exposure to moderately elevated ozone. Environ. Pollution, 158 (2), 440, 2010.

29. VULETIĆ M. V., DUGALIĆ Kr., MIHALJEVIĆ I., TOMAŠ V., VUKOVIĆ D., ZDUNIĆ Z., PUŠKAR B., JURKOVIĆ Z. Season, location and cultivar influence on bioactive compounds of sour cherry fruits. Plant Soil Environ, 63 (9), 389, 2017.

30. YANG L., ZHAO Y., ZHANG Q., CHENG L., HAN M., REN Y., YANG L. Effects of drought-re-wateringdrought on the photosynthesis physiology and secondary metabolite production of Bupleurum chinense DC. Plant Cell Rep, 38 (9), 1181-1197, 2019. https ://doi. org/10.1007/ s0029 9-019-02436-8.

31. TOPLU C., ÖNDER D., ÖNDER S., ERCAN Y. Determination of fruit and oil characteristics of olive (Olea europaea L. cv. 'Gemlik') in different irrigation and fertilization regimes. Afr J of Agr Research, 4 (7), 649, 2009.

32. BOUHAFA K., MOUGHLI L., BOUABID R., DOUAIK A., TAARABT Y. Dynamics of macronutrients in olive leaves. Journal of plant nutrition, 41 (4), 1, 2018.

33. BEN MANSOUR-GUEDDES S., SAIDANA D., CHERAIEF I., DKHILALI M., BRAHAM M. Biochemical, Mineral and Anatomical characteristics of the Olive Tree cv. Chetoui Growing in Several Tunisian Areas. Acta Scient. Pol. Hort. Cultus, 17 (2), 49, 2018.

34. CONNELL J.H., VOSSEN P.M. Organic olive orchards nutrition. In: Organic olive production manuel, Vossen, P.M. (ed.). Publ, 3505, University of California, Oakland, 37, 2007.

35. BRAHAM M. Evaluation des exportations en azote, en phosphate et en Potassium d'un hectare d'olivier 'Chemlali' (Olea europaea L.). Revue Ezzaitouna, 5, 1, 1999.

36. BRAHAM M. Evolution des réserves minérales et carbonées chez les variétés d'Olivier à huile «Chétoui» et «Chemlali» (Olea europaea. L). Memoire de $3^{\text {éme }}$ Cycle de spécialisation Oléiculture- Oléotechnie, INAT, 1984.

37. BEN KHELIL M. Evaluation du statut nutritionnel de l'Olivier (Olea europaea) par la méthode du diagnostique floral. Thesis, National Institute of Agronomy of Tunisia, Tunis, 2010.

38. ZHONG C., CAO X., HU J., ZHU L., ZHANG J., HUANG J., JIN Q. Nitrogen Metabolism in Adaptation of Photosynthesis to Water Stress in Rice Grown under Different Nitrogen Levels. Frontiers in Pl Sci, 8 (1079), 1, 2017.

39. DA-SILVA E.C., MANSUR CUSTÓDIO NOGUEIRA R.J., DA SILVA M.A., DE ALBUQUERQUE M.B. Drought Stress and Plant Nutrition. Plant Stress, Global Science Books, 5 (1), 32, 2011.

40. CETINKAYAA H., KOCA M., KULAK M. Monitoring of mineral and polyphenol content in olive leaves under drought conditions: Application Chemometric Techniques. Ind Crop Prod, 88, 78, 2016.

41. JIN J., WANG G., LIU X., PAN X., HERBERT S.J., TANG C. Interaction between phosphorus nutrition and drought on grain yield, and assimilation of phosphorus and nitrogen in two soybean cultivars differing in protein concentration in grains. Journal of Plant Nut, 29, 1433, 2006.

42. FERNÁNDEZ J.E. Understanding olive adaptation to abiotic stresses as a tool to increase crop performance., 103, 158, 2014

43. EREL R., BEN-GAL A., DAG A., SCHWARTZ A. and YERMIYAHU U. Sodium replacement of potassium 
in physiological processes of olive trees (var. Barnea) as affected by drought. Tree Physiology, 00, 1, 2014. doi:10.1093/treephys/tpu081.

44. ARMENGAUD P., SULPICE R., MILLER A.J., STITT M., AMTMANN A., GIBON Y. Multilevel analysis of primary metabolism provides new insights into the role of potassium nutrition for glycolysis and nitrogen assimilation in Arabidopsis roots. Plant Physiology, 150, 772, 2009.

45. BOUSSADIA O., BCHIR A., STEPPE K., VAN LABEKE M.C., LEMEUR R., BRAHAM M. Active and passive osmotic adjustment in olive tree leaves during drought stress. Eu Sci J, 9 (24), 1857, 2013.

46. KAFKAFI U. The functions of plant $\mathrm{K}$ in overcoming environmental stress situations. In: Proc. $22^{\text {nd }}$ colloquium of IPI, pp. 81-93, held in Soligorsk, USSR, IPI, Bern. 1990.

47. ALINIAEIFARD S., SHOMALI A., SEIFIKALHOR M., LASTOCHKINA O. Calcium Signaling in Plants under Drought. In: Salt and Drought Stress Tolerance in Plants Signaling Networks and Adaptive mechanisms; Hasanuzzaman M., Tanveer M. Eds., Springer Nature, Switzerland, 259, 2020.

48. HOSSEINI S.A., RÉTHORÉ E., PLUCHON S., ALI N., BILLIOT B., YVIN J.C. Calcium Application Enhances Drought Stress Tolerance in Sugar Beet and Promotes Plant Biomass and Beetroot Sucrose Concentration. Inter J of Mol Sci, 20, 3777, 1, 2019.
49. KANT S., KAFKAFI U. Potassium and abiotic stresses in plants. In: Role of potassium in nutrient management for sustainable crop production in India. Pasricha, N.S. and S.K. Bansal (eds.). Potash Research Institute of India, Guargaon, Haryana, India, 233, 2002.

50. BUSTAN A., AVNI A., YERMIYAHU U.A., RIOV J., EREL R., ZIPORI I., DAG A. Interactions between fruit load and macro-element concentrations in fertigated olive (Olea europaea L.) trees under arid saline conditions. Sci Horticulturea, 152, 44, 2013.

51. WAKEEL A., FAROOQ M., QADIR M., SCHUBERT S. Potassium Substitution by Sodium in Plants. Critical Reviews in Plant Sci, 30 (4), 401, 2011.

52. BEN MANSOUR-GUEDDES S., SAIDANA-NAIJA D., JABNOUN-KHIAREDDINE H., BCHIR A., DAAMIREMADI M., BRAHAM M. Chemical composition and biological activity of three olive cultivar volatiles. Acta Scientiarum Pol Hort Cultus, 19 (4), 3, 2020.

53. SAIDANA-NAIJA D., BEN MANSOUR-GUEDDES S., FLAMINI G., JABNOUN-KHIAREDDINE H., DAAMI-REMADI M., BEN MARIEM F., GHARIANI W., BRAHAM M. Assessment of Antioxidant and Antimicrobial Compounds of Volatiles from Leaves, Stems and Flowers of Olives. Pol J Environ Stud, 30 (2), $1,2021$. 